DEPARTMENT OF THE INTERIOR UNITED STATES GEOLOGICAL SURVEY

PREPARED IN COOPERATION WITH THE

STATE OF CONNECTICUT

GEOLOGICAL AND NATURAL HISTORY SURVEY

\title{
AEROMAGNETIC MAP OF THE FITCHVILLE QUADRANGLE AND PART OF THE NORWICH QUADRANGLE, NEW LONDON COUNTY, CONNECTICUT
}

\author{
GEOPHYSICAL INVESTIGATIONS \\ MAP GP- 860
}

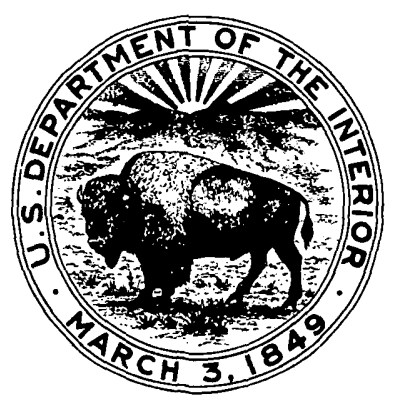

PUBLISHED BY THE U.S. GEOLOGICAL SURVEY WASHINGTON, D.C. 20242 